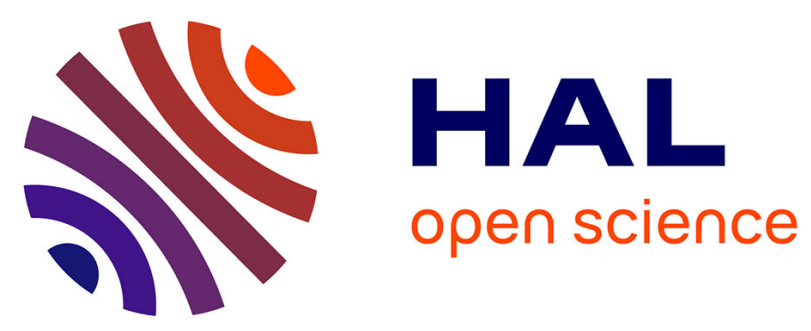

\title{
Validation of a new method for monitoring trace elements in Mediterranean cereal soils
}

\author{
Nada Lebbos, Catherine Keller, Laurence Dujourdy, Michel Afram, Pierre \\ Curmi, Talal Darwish, Claude Daou, Elias Bou-Maroun
}

\section{To cite this version:}

Nada Lebbos, Catherine Keller, Laurence Dujourdy, Michel Afram, Pierre Curmi, et al.. Validation of a new method for monitoring trace elements in Mediterranean cereal soils. International Journal of Environmental Analytical Chemistry, 2021, pp.1-17. 10.1080/03067319.2021.1953000 . hal-03337034

\section{HAL Id: hal-03337034 \\ https://institut-agro-dijon.hal.science/hal-03337034}

Submitted on 27 Jan 2022

HAL is a multi-disciplinary open access archive for the deposit and dissemination of scientific research documents, whether they are published or not. The documents may come from teaching and research institutions in France or abroad, or from public or private research centers.
L'archive ouverte pluridisciplinaire HAL, est destinée au dépôt et à la diffusion de documents scientifiques de niveau recherche, publiés ou non, émanant des établissements d'enseignement et de recherche français ou étrangers, des laboratoires publics ou privés. 


\section{Validation of a new method for monitoring trace elements in Mediterranean cereal soils}

Nada Lebbos ${ }^{\mathrm{a}}$, Catherine Keller ${ }^{\mathrm{b}}$, Laurence Dujourdy ${ }^{\mathrm{c}}$, Michel Afram ${ }^{\mathrm{a}}$, Pierre Curmi $^{\mathrm{d}}$, Talal Darwish ${ }^{\mathrm{e}}$, Claude Daou ${ }^{\mathrm{f}}$, Elias Bou-Maroun ${ }^{\mathrm{g} *}$

${ }^{a}$ Lebanese Agricultural Research Institute LARI, Beirut PO Box 90-1965, Lebanon; ${ }^{b}$ Aix Marseille Univ., CNRS, IRD, INRAe, Coll France, CEREGE, Technopôle de l'Environnement Arbois-Méditerranée, BP 80, F-13545 Aix-en-Provence, France; ${ }^{c}$ AgroSup Dijon, Service d'Appui à la recherche, F-21000 Dijon, France; ${ }^{d}$ AgroSup Dijon, Univ. Bourgogne Franche-Comté, Biogéosciences UMR 6282, F-21000 Dijon, France; ${ }^{e}$ National Center for Remote Sensing, National Council for Scientific Research (CNRS), Riad al Soloh, Beirut 1107 2260, Lebanon; ${ }^{f}$ Lebanese University, Faculty of Science II, Laboratoire d'Analyse Chimique (LAC), Fanar PO Box 90656, Lebanon; ${ }^{g}$ AgroSup Dijon, Univ. Bourgogne Franche-Comté, PAM UMR A 02.102, Procédés Alimentaires et Microbiologiques, F-21000 Dijon, France

* Corresponding author: elias.bou-maroun@ agrosupdijon.fr; Tel.: + 33380774080

To cite this article:

Nada Lebbos, Catherine Keller, Laurence Dujourdy, Michel Afram, Pierre Curmi, Talal Darwish, Claude Daou \& Elias Bou-Maroun (2021) Validation of a new method for monitoring trace elements in Mediterranean cereal soils, International Journal of Environmental Analytical Chemistry, DOI: 10.1080/03067319.2021.1953000 


\section{Validation of a new method for monitoring trace elements in Mediterranean cereal soils}

In the Mediterranean region, agricultural soils are seriously polluted with toxic trace elements (TEs) which could enter the food chain via the soil-plant trophic chain. For food safety reasons, the monitoring of TE concentrations in these agricultural soils is thus imperative. The most powerful monitoring method for TE measurements is based on perchloric acid $\left(\mathrm{HClO}_{4}\right)$ and hydrofluoric acid (HF) digestion, commonly used as reference total digestion (RTD) method, with consequent use of inductively coupled plasma optical emission spectrometry (ICPOES) and inductively coupled plasma mass spectrometry (ICP-MS). Unfortunately, $\mathrm{HF}$ and $\mathrm{HClO}_{4}$ manipulations are highly dangerous and ICP-OES and ICP-MS apparatus are very expensive, thus they are unaffordable, notably in developing countries. In this paper, an alternative, microwave sulphuric digestion (MSD) method, combined with atomic absorption spectroscopy (AAS) is proposed. First, the suggested method was validated on a soil certified reference material, for the determination of 7 TEs (As, $\mathrm{Cd}, \mathrm{Co}, \mathrm{Cr}, \mathrm{Cu}, \mathrm{Ni}$ and $\mathrm{Pb}$ ). Second, the MSD method was applied on agricultural soil samples situated in the Bekaa valley, East Lebanon and results were compared to those of RTD method. The MSD method, coupled to AAS, offers a promising and feasible alternative to HF, as well as, aqua regia based methods.

Keywords: method validation; trace elements; soil; microwave digestion; atomic absorption spectroscopy; Bekaa; East Mediterranean.

\section{Introduction}

Trace elements (TEs) are the most studied soil contaminants in the world, and come both from lithogenic sources [1] and anthropogenic activities [2]. They are persistent, nondegradable and even though some are essential for living organisms, they can adversely affect microorganisms, animals, plants and humans at high concentrations. As a matter of fact, TEs can accumulate in plants to harmful concentrations, becoming a threat for human health through the food chain [3]. Accurate and routine determination of their concentration in soil is thus necessary to assess their risk to directly and indirectly enter 
the food chain.

Cereal production soils in the Mediterranean basin are regularly amended with organic matter and phosphates bearing TEs and repeatedly irrigated with untreated wastewater [4,5]. A regular monitoring of TE concentrations in these agricultural soils is of great interest. Arsenic, $\mathrm{Cd}, \mathrm{Co}, \mathrm{Cr}, \mathrm{Cu}, \mathrm{Ni}$ and $\mathrm{Pb}$ are the most monitored elements based on previous studies of TE determination in cereal production soils of the Bekaa valley, East Lebanon [6]. Nevertheless, less than $6 \%$ of Lebanese arable lands have been checked so far for TE contamination [7].

Although some countries introduced the nondestructive thick target particle induced X-ray emission technique for the determination of trace elements in as received soil samples, digestion methods are still widely practiced [8]. However, the heterogeneous and complex soil matrix, associating organic compounds and mineral constituents with different physicochemical characteristics, does not allow a single solid phase digestion method for the determination of TEs. To be acceptable, precision and accuracy for digestion methods should be lower than $20 \%$ [9] for any set of targeted soil to be analysed on a routine basis.

The digestion of samples containing TEs can be done using a dry method: in this case, the sample is calcined in an oven at temperatures ranging between $450^{\circ} \mathrm{C}$ and $500^{\circ} \mathrm{C}$. Dry ashing offers the advantage of requiring few reagents like acids to solubilize ashes. However, dry ashing can lead to a loss of analytes like As and $\mathrm{Hg}$ by volatilization.

To reduce the sample preparation time and losses by volatilization, wet digestion processes are an attractive alternative to dry ashing methods for several samples such as biological tissues, food and soils [3,10]. In this case, the sample is mineralized in a mixture of acid at their boiling point. Different acids are usually used to perform the wet 
mineralization: hydrochloric acid $(\mathrm{HCl})$, nitric acid $\left(\mathrm{HNO}_{3}\right)$, sulfuric acid $\left(\mathrm{H}_{2} \mathrm{SO}_{4}\right)$, perchloric acid $\left(\mathrm{HClO}_{4}\right)$, hydrofluoric acid (HF). Several combinations were used for the mineralization of soil samples [11-14] but there is no consensus on the choice of the mineralization reagent.

It is admitted that $\mathrm{HF}$ combined with $\mathrm{HClO}_{4}$ allows for a total dissolution of all elements present in the sample but induces Si volatilization. However, HF is dangerous to handle. High precautions and safe handling should be implemented in the laboratory to prevent accidents. Despite this, serious accidents can always occur.

To avoid handling HF, sample attacks using a mixture of other strong acids are usually adopted in routine analysis. $\mathrm{HNO}_{3}$ has high oxidant properties, most often used in wet mineralization, especially when the analysis step is done by atomic absorption technics [15]. Its relatively low boiling point $\left(120^{\circ} \mathrm{C}\right)$ limits its efficiency. Therefore, $\mathrm{HNO}_{3}$ is commonly used in a mixture with $\mathrm{H}_{2} \mathrm{SO}_{4}$ or $\mathrm{HClO}_{4}$ (boiling point at $340^{\circ} \mathrm{C}$ and $200^{\circ} \mathrm{C}$ respectively). $\mathrm{HClO}_{4}$ should be handled carefully because when its concentration exceeds $85 \%$ above $150^{\circ} \mathrm{C}$, it becomes unstable and presents a serious explosion hazard. The combination of $\mathrm{HNO}_{3}$ with $\mathrm{HCl}$ is well-known as "aqua regia mixture". It has a high dissolution power and is usually used to evaluate the trace element contamination level [16]. Aqua regia reagent gives a pseudo-total concentration compared with the HF total method, especially for the following elements ( $\mathrm{Cr}, \mathrm{Ni}, \mathrm{Zn}$ and $\mathrm{Pb})$ [17].

Ammonium fluoride $\left(\mathrm{NH}_{4} \mathrm{~F}\right)$ and ammonium bifluoride $\left(\mathrm{NH}_{4} \mathrm{HF}_{2}\right)$ are used as a substitute for HF. These compounds are safer than HF for the operator and have high boiling points $\left(260{ }^{\circ} \mathrm{C}\right.$ and $\left.239.5^{\circ} \mathrm{C}\right)$ allowing sample digestion at high temperature in open vessels [18]. 
To optimize the mineralization time, microwave heating is often performed. Hydrogen peroxide $\left(\mathrm{H}_{2} \mathrm{O}_{2}\right)$ is largely used in mixture with strong acids for the oxidation and destruction of organic matter [11-13]. Its oxidation power is greatly enhanced in the presence of $\mathrm{H}_{2} \mathrm{SO}_{4}$ due to the formation of $\mathrm{H}_{2} \mathrm{SO}_{5}$ [15]. Recently, Magladi et al. [19] used a mixture of $\mathrm{NH}_{4} \mathrm{HF}_{2}$ and $\mathrm{HNO}_{3}$ in a microwave oven to dissolve completely a wide range of silicate rock samples for trace element determination. Certain analytes were not fully recovered using this method which limits its field of application.

Most often, TEs concentration in the mineralization solutions is determined using inductively coupled plasma optical emission spectrometry (ICP-OES) and inductively coupled plasma mass spectrometry (ICP-MS) following ISO 22036 [20] and ISO 172942 [21] standards. These devices are very expensive and have high maintenance costs but combines low detection limits and a rapid multi-elemental determination in comparison with atomic absorption spectroscopy (AAS). Therefore, it is important to have available a method for TE analysis that is safe, green, inexpensive and accessible to a large number of laboratories. In agreement with green analytical chemistry, an eco-friendly infrared digestion method was recently developed for multi-element determination in soil sample by microwave induced plasma atomic emission spectrometry (MIP-OES) [22]. This method minimizes the reagents amounts, makes digestion safer and reduces waste.

The choice of a sample preparation method is crucial in the analysis of soil and sediment samples. Proper choice reduces matrix effects in complex samples and subsequently limits spectral and non-spectral interferences. The latter involves sampleintroduction and plasma related-interferences. This last point becomes very important when using plasma-based atomic emission like ICP-OES and IC-PMS. Nitric acid is usually used to avoid spectral interferences caused by other acids [23]. 
In this study, two digestion methods were compared using a soil certified reference material: 1) heating 3 acid digestion (HAD) with a mixture of $\mathrm{HNO}_{3}, \mathrm{HClO}_{4}$ and $\mathrm{H}_{2} \mathrm{SO}_{4}$, and 2) microwave sulfuric digestion (MSD) using a mixture of $\mathrm{H}_{2} \mathrm{SO}_{4}$ and $\mathrm{H}_{2} \mathrm{O}_{2}$. The latter is proposed as a green, simple and fast method for soil sample digestion. The use of $\mathrm{H}_{2} \mathrm{SO}_{4}$ in sample digestion in combination with $\mathrm{H}_{2} \mathrm{O}_{2}$ is more advantageous than the use of $\mathrm{NH}_{4} \mathrm{~F}$ and $\mathrm{NH}_{4} \mathrm{~F}_{2}$. The latter are safer than $\mathrm{HF}$ but remain more dangerous than $\mathrm{H}_{2} \mathrm{SO}_{4}$.

The measurement of $\mathrm{As}, \mathrm{Cd}, \mathrm{Co}, \mathrm{Cr}, \mathrm{Cu}, \mathrm{Ni}$ and $\mathrm{Pb}$ concentrations was then conducted using a flame atomic absorption spectrometer (AAS). AAS is less efficient than the widely used plasma based methods (ICP-OES and ICP-MS) because it is less sensitive and only allows the determination of single elements. However, AAS is cheaper than plasma based methods and is available to a large number of laboratories. A validation of the selected digestion method was done using a certified reference material (CRM). Afterward, the validated method (MSD + AAS) was applied on agricultural soil samples collected from the Bekaa region, located in Lebanon, East Mediterranean. The results were compared to those obtained using the reference total digestion method (RTD) (HF-based digestion + ICP/ICPMS).

\section{Material and methods}

\subsection{Chemicals}

The standard solutions for the elements $\mathrm{As}, \mathrm{Cd}, \mathrm{Co}, \mathrm{Cr}, \mathrm{Cu}, \mathrm{Ni}$ and $\mathrm{Pb}$ of concentrations $1000 \pm 1 \mathrm{mg} \mathrm{L}^{-1}$ were obtained from Sigma-Aldrich. Nitric acid $\mathrm{HNO}_{3} 65 \%$, extra pure, sulphuric acid $\mathrm{H}_{2} \mathrm{SO}_{4} 95 \%$ and, perchloric acid $\mathrm{HClO}_{4} 70 \%$ and hydrogen peroxide $\mathrm{H}_{2} \mathrm{O}_{2}$ $30 \%$, obtained from Sigma-Aldrich, were used for digestion. A $1 \% \mathrm{HNO}_{3}$ nitric acid was prepared from concentrated acid $\left(65 \% \mathrm{HNO}_{3}\right)$ and was used in the standard solution 
preparation. Ultrapure water $\left(>18 \mathrm{M} \Omega \mathrm{cm}^{-1}\right)$ was obtained from a Milli-Q apparatus (Boeco pure, Germany). The Certified Reference Material (CRM) (SQC001-LRAA8753) for trace elements ( $\mathrm{As}, \mathrm{Cd}, \mathrm{Co}, \mathrm{Cr}, \mathrm{Cu}, \mathrm{Ni}$ and $\mathrm{Pb}$ ) in soil was purchased from Sigma Aldrich.

\subsection{Sites and sampling}

Lebanon is located in the eastern Mediterranean basin between $35^{\circ}$ and $36^{\circ} 40^{\prime} \mathrm{E}$ and between $33^{\circ}$ and $34^{\circ} 40^{\prime} \mathrm{N}$. The Bekaa Valley, an agricultural region where more than $90 \%$ of Lebanese wheat production is produced [24], is mainly a plain area located between Mount Lebanon in the west and the Anti-Lebanon mountains to the East. Eight sites where soil samples were taken are selected along a transect crossing the central Bekaa valley from southwest to northeast (Figure 1). The soils of the sampling sites are Eutric and Vertic Cambisols (B1, B2, B5, B6 and B7), and Eutric Fluvisols (B3, B4ab and B8) according to the World Reference Base [25]. They are deep, predominantly noncalcareous clay, with neutral to weakly basic $\mathrm{pH}$ values $(7.4-7.8)$ and low to medium organic matter $(1.4 \%-2.7 \%)$.

Most of these sites were irrigated by private tube wells taking water from the deep groundwater reservoir, and by surface waters when available nearby (Berdawni and Litani rivers). Farmers generally practice an annual wheat/potato succession.

Topsoil layer $(0-20 \mathrm{~cm})$ was sampled using a stainless-steel shovel at the corners of the plot, in the centre and diagonally. The nine subsamples of the same plot were mixed, homogenized and carried in clean polyethylene bags. The samples were then brought to the laboratory where a quartering technique [26] was applied to the overall homogenized sample to reduce the sample size and form a composite sample. Only about $1 \mathrm{~kg}$ of soil sample underwent pretreatment. 


\subsection{Samples pretreatment and digestion}

The composite soil samples were cleaned up from roots and gravels, dried according to the AFNOR NF X31-102 standard [27] in an oven (Model 700 Memmert) at $40^{\circ} \mathrm{C}$, until constant weight and sieved at $2 \mathrm{~mm}$. Then, soil samples were stored in plastic bottles protected from the direct sunlight and at a temperature below $4^{\circ} \mathrm{C}$ (in the refrigerator) until analysis.

Before mineralization, the soil samples were ground fine with a mortar and sieved (diameter $<250 \mu \mathrm{m}$ ) following the standard NF ISO 11464 [28]. Two methods of digestion were used in order to mineralize a representative part of the composite soil samples:

i) For the heating 3 acid digestion (HAD), a three-acid mixture $\left(9 \mathrm{~mL} \mathrm{HNO}_{3}, 2 \mathrm{~mL}\right.$ $\mathrm{HClO}_{4}, 2 \mathrm{~mL} \mathrm{H}_{2} \mathrm{SO}_{4}$ ) was added to $0.5 \mathrm{~g}$ of soil sample or CRM, followed by heating up to $350^{\circ} \mathrm{C}$ for $2 \mathrm{~h} 30 \mathrm{~min}$ in a heating block. The mixture was then stored at room temperature for one night. ii) For the microwave sulphuric digestion (MSD), a microwave type "Milestone - Ethos Easy" was used. Fifteen vessels can be processed simultaneously This system controls the temperature in all vessels using a direct contactless temperature sensor. An acid mixture of $9 \mathrm{~mL}$ of $\mathrm{H}_{2} \mathrm{SO}_{4}$ and $3 \mathrm{~mL}$ of $\mathrm{H}_{2} \mathrm{O}_{2}$ was added to $0.5 \mathrm{~g}$ of soil sample or CRM in a Teflon receptacle tightly closed. A temperature of $200{ }^{\circ} \mathrm{C}$ was reached in $10 \mathrm{~min}$ and maintained at this level $10 \mathrm{~min}$. Then, the temperature decreased gradually where the cooling step was maintained for $20 \mathrm{~min}$. This method was suggested by Milestone and was subjected to a validation.

All digested samples were filtered and adjusted to $25 \mathrm{~mL}$ using $\mathrm{HNO}_{3} 1 \%$ before analysis.

\subsection{Apparatus for TE analysis}

The analyses of TEs were conducted by atomic absorption spectrometry (flame iCE 3000 
series - Thermo type, Thermo Fischer Scientific, Germany). An acetylene/air flame was used. Liquid samples were introduced in the spectrometer with an auto sampler using blank and standards for the analysis of the following elements: $\mathrm{As}, \mathrm{Cd}, \mathrm{Co}, \mathrm{Cr}, \mathrm{Cu}, \mathrm{Ni}$ and $\mathrm{Pb}$.

Calibration standard solutions were prepared by successive dilution, all plastic labware used for sampling and sample treatment was new or cleaned by soaking $24 \mathrm{~h}$ first in $10 \% \mathrm{HNO}_{3}$ then in ultra-pure water.

\subsection{Official or reference methods for trace element analysis}

For the reference total digestion (RTD) method, soil sample mineralization was done by a mixture of $\mathrm{HF}(5 \mathrm{~mL})$ and $\mathrm{HClO}_{4}(1.5 \mathrm{~mL})$ acids added to $0.25 \mathrm{~g}$ previously ground soil below $250 \mu \mathrm{m}$ following the standard ISO 14869-1 [29] (details are given in Supplementary Materials SM1). HF decomposes silicates to from volatile $\mathrm{SiF}_{4}$. The use of $\mathrm{HClO}_{4}$ is necessary to avoid the precipitation of calcium in the form of fluoride $\left(\mathrm{CaF}_{2}\right)$. To avoid the risks of a brutal oxidation (acid ejection) of the organic matter (OM) by $\mathrm{HClO}_{4}$, the $\mathrm{OM}$ was previously destroyed by calcining at $450^{\circ} \mathrm{C}$. The hydrofluoric and perchloric acids were eliminated by evaporation at the end of the reaction. The residue was dissolved in diluted nitric acid $2 \%$. Trace elements $\mathrm{Co}, \mathrm{Cr}, \mathrm{Cu}$ and $\mathrm{Ni}$ were then analysed by Inductively Coupled Plasma Atomic Emission Spectroscopy (ICP-OES, Vista Pro, Varian, France) following the standard ISO 22036 [20], while As, Cd and Pb were analysed by Inductively Coupled Plasma Mass Spectrometry (ICP-MS, Thermo series 2, France) following the standard ISO 17294-2 [21].

\subsection{Statistical analysis}

All calculations related to the working range, linearity domain, limit of detection and 
limit of quantification were realised using R-4.0.0 [30] and RStudio 1.2.5042 [31] with packages: “car” [32], "lmtest” [33] and "dplyr" [34].

Analysis of variance was performed using XLSTAT 2018 to calculate repeatability and intermediate precision.

Information about various statistical analysis are detailed in following paragraphs, especially in section 3.2.1 for working range, linearity domain, limit of detection and limit of quantification and 3.2.2. for repeatability and intermediate precision.

\section{Results and Discussion}

\subsection{Choice of the best digestion method using the soil Certified Reference Material CMR (SQC001)}

To choose the best digestion method, the heating 3 acid digestion (HAD) and the microwave sulfuric digestion (MSD) methods were both applied on the soil CRM (SQC001).

$\mathrm{HNO}_{3}$ is the most used acid in wet digestion. To overcome its limited efficiency due to its low boiling point, it was used in combination with $\mathrm{H}_{2} \mathrm{SO}_{4}$ and $\mathrm{HClO}_{4}$ for the HAD digestion. Moreover, $\mathrm{HClO}_{4}$ ameliorate the dissolution of sediment samples and insure a complete recovery of trace elements [35]. For the MSD digestion, $\mathrm{H}_{2} \mathrm{SO}_{4}$ was used because it has the highest boiling point. A mixture of $\mathrm{H}_{2} \mathrm{SO}_{4}$ and $\mathrm{H}_{2} \mathrm{O}_{2}$ was used because $\mathrm{H}_{2} \mathrm{SO}_{4}$ enhances the oxidation power of $\mathrm{H}_{2} \mathrm{O}_{2}$.

After digestion, the TEs As, $\mathrm{Cd}, \mathrm{Co}, \mathrm{Cr}, \mathrm{Cu}, \mathrm{Ni}$ and $\mathrm{Pb}$ were determined by AAS. The relative recovery, expressed in percentage was calculated using the following equation (Equation 1): 


$$
R(\%)=\frac{\bar{x}}{x_{\text {ref }}} \times 100
$$

where $\bar{x}$ is the mean of CRM after digestion of the sample in triplicate, and $x_{r e f}$ is the assigned property value of CRM.

For the HAD method, the relative recovery for the elements analysed by AAS varied between $51.5 \%$ and $90.0 \%$ (Table 1). These values were very low and showed that the $\mathrm{HAD}$ method using the mixture $\mathrm{HNO}_{3}, \mathrm{HClO}_{4}, \mathrm{H}_{2} \mathrm{SO}_{4}$ was not efficient enough to sufficiently solubilize the analysed trace elements.

Table 1: Comparison of the heating 3 acid digestion method (HAD) and the microwave sulphuric digestion method (MSD) using their relative recovery percentage of the soil Certified Reference Material CMR (SQC001)

\begin{tabular}{|c|c|c|c|c|c|}
\hline \multirow[t]{2}{*}{ Element } & \multirow{2}{*}{$\begin{array}{c}\text { Soil CRM } \\
\begin{array}{c}\text { Assigned value } \pm \text { SD } \\
\mathrm{mg} \mathrm{kg}^{-1}\end{array}\end{array}$} & \multicolumn{2}{|c|}{ HAD method } & \multicolumn{2}{|c|}{ MSD method } \\
\hline & & 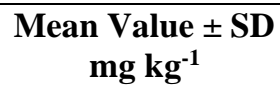 & $\begin{array}{c}\text { Recovery } \\
\%\end{array}$ & $\begin{array}{c}\text { Mean Value } \pm \text { SD } \\
\text { mg kg }^{-1}\end{array}$ & $\begin{array}{c}\text { Recovery } \\
\%\end{array}$ \\
\hline As & $161.0 \pm 3.6$ & $115.3 \pm 1.0$ & 71.6 & $150.9 \pm 1.2$ & 93.7 \\
\hline $\mathrm{Cd}$ & $190.0 \pm 3.9$ & $154.6 \pm 1.1$ & 81.4 & $165.9 \pm 2.4$ & 87.3 \\
\hline Co & $177.0 \pm 3.6$ & $91.2 \pm 1.0$ & 51.5 & $199.3 \pm 4.7$ & 112.6 \\
\hline $\mathrm{Cr}$ & $87.9 \pm 2.3$ & $67.8 \pm 0.7$ & 77.1 & $98.7 \pm 1.0$ & 112.3 \\
\hline $\mathrm{Cu}$ & $258.0 \pm 5.3$ & $232.3 \pm 0.3$ & 90.0 & $230.1 \pm 2.3$ & 89.2 \\
\hline $\mathrm{Ni}$ & $127.0 \pm 3.2$ & $111.2 \pm 1.1$ & 63.5 & $125.0 \pm 1.1$ & 98.4 \\
\hline $\mathrm{Pb}$ & $138.0 \pm 4.0$ & $80.6 \pm 1.2$ & 80.6 & $155.4 \pm 1.0$ & 112.6 \\
\hline
\end{tabular}

$\overline{\mathrm{SD}}=$ Standard deviation

For the MSD method, the relative recovery was in general higher and varied between $87.3 \%$ and $112.6 \%$. These values were close to $100 \%$ and are within the accepted range for TE analysis (80 - 120\%) [36]. Results show that sulphuric acid along with $\mathrm{H}_{2} \mathrm{O}_{2}$ represents an efficient mixture to solubilize TEs from different soil types, especially when microwave heating is used. 
As the microwave sulphuric digestion of CRM gave acceptable recovery percentages, a validation procedure using this method was performed to check its applicability in our laboratory for trace element analysis in some Mediterranean soils.

\subsection{Validation of the microwave sulphuric digestion method followed by AAS using the soil Certified Reference Material CMR (SQC001)}

To validate the new digestion using a mixture of $\mathrm{H}_{2} \mathrm{SO}_{4}$ and $\mathrm{H}_{2} \mathrm{O}_{2}$, before applying it for trace element analysis in the soils, the following parameters were considered and determined: working range including linearity, limit of detection of the analytical system (LOD), limit of quantification (LOQ), precision including repeatability and intermediate precision, specificity and trueness.

\subsubsection{Working range, linearity domain, limit of detection (LOD) and limit of quantification (LOQ)}

The linearity of a method is often confused with the linearity of the instrument calibration function. In fact, the linearity of a method characterizes its accuracy, whereas instrumental linearity is concerned only with its own response. However, a response function does not have to be linear for correct quantification. Many methods make effective use of calibration models that are much more complex than just linearity $[37,38]$.

Calibration curves for each measured element were built using 4 or 5 points, depending on the element, each point was triplicated. For some elements, quadratic regression $y=$ $\beta_{0}+\beta_{1} x+\beta_{2} x^{2}+\varepsilon$ gave better results and for some others, the best fit model was linear regression: $y=\beta_{0}+\beta_{1} x+\varepsilon$. It can happen when wide dynamic ranges and/or not isotopically pure internal standards are considered (especially true in mass spectrometry) [39]. The independent variable $x$ is assumed unaffected by error. $\beta_{0}, \beta_{1}$, and $\beta_{2}$ are the 
parameters of the model and $\varepsilon$ represents a normally distributed random error, with mean zero and constant variance $\sigma^{2}$ [homoscedastic condition and $\left.\varepsilon \sim \mathcal{N}\left(0, \sigma^{2}\right)\right]$. The $\beta$ parameters are unknown and ordinary least-squares regression provides their estimates "b" by using a set of experimental data points $\left(\mathrm{x}_{\mathrm{i}}, \mathrm{y}_{\mathrm{i}}\right)[40]$.

The adequacy of the model has been tested in several ways: (i) by the use of an analysis of variance test (ANOVA) called the lack of fit test (with replicate data) [41]; (ii) by inspection of the behaviour of the residuals and (iii) by the evaluation of the determination coefficient $\mathrm{R}^{2}$ (square of correlation coefficient $\mathrm{r}$ ). Models and main results of ANOVA tests are summarized in Table 2 and Table 3. More results are given in

\section{Supplementary Materials SM2 and SM3.}

Estimated coefficients $b_{1}$ and $b_{2}$ were significantly different from zero and $b_{0}$ coefficient, depending on element, was not significantly different from zero. The limit of detection (LOD) and the limit of quantification (LOQ) were calculated using the following equations [42]:

$$
L O D=\frac{3}{b_{1}} \sqrt{\frac{s_{B l}^{2}}{n_{B l}}+s_{b_{0}}^{2}}
$$

Where $b_{1}$ is the sensitivity and, $s_{B l}$ is the standard deviation of the blank measurements, $n_{B l}$ is the number of blank measurements and $s_{b_{0}}$ is the standard deviation of the intersection with the vertical axis. In case of the quadratic model, when the instrument detector is working close to zero concentrations, the contribution of the $2^{\text {nd }}$ degree term in the calibration curve is negligible.

$$
\mathrm{LOQ} \cong 3 \times \mathrm{LOD}
$$


Table 2. Calibration curves of the measured elements

\begin{tabular}{|c|c|c|}
\hline Element & Model & $\begin{array}{l}\text { Residual behaviour (normality, homoscedasticity, } \\
\text { independence) }\end{array}$ \\
\hline As & & \\
\hline $\mathrm{Cd}$ & $c$ & Passed except \\
\hline $\mathrm{Co}$ & & Passed except \\
\hline $\mathrm{Cr}$ & $1 \mathrm{ml}$ & Passed excepted autocorrelation * \\
\hline $\mathrm{Cu}$ & & \\
\hline $\mathrm{Ni}$ & lin & Passed excepted normality \& autocorrelation, presence of 1 ou \\
\hline $\mathrm{Pb}$ & quadratic & Passed \\
\hline \multicolumn{3}{|c|}{$\begin{array}{l}\text { * Due to the presence of one or two extreme values (checked with Bonferroni Outlier Test) [32]. The } \\
\text { calculation of a reliable calibration model needed in general many values to be at least between } 8 \text { and } 10 \\
\text { to verify the normality of the data by the Shapiro-Wilk test (Shapiro \& Wilk, 1965) for instance, and to } \\
\text { ascertain their scedasticity; and the number of concentration levels must range between } 7 \text { and } 10 \text { [43]. Ir } \\
\text { this study, the number of levels is between } 4 \text { and } 5 \text { with } 3 \text { replicates. So, the calibration models were } \\
\text { evaluated with and without extreme values and coefficients were not drastically affected. It was decided to } \\
\text { keep them. }\end{array}$} \\
\hline
\end{tabular}

Table 3. Working ranges, regression equations, limit of detection (LOD) and limit of quantification (LOQ) of the measured elements

\begin{tabular}{|c|c|c|c|c|c|c|}
\hline Element & $\begin{array}{l}\text { Working } \\
\text { range } \\
\text { mg kg-1 }^{-1}\end{array}$ & $\begin{array}{c}\text { Regression equation } \\
\mathbf{y}=\mathbf{a x}+\mathbf{b x}+\mathbf{c} \\
\text { or } \mathbf{y}=\mathbf{a x}+\mathbf{b}\end{array}$ & $\begin{array}{c}\text { Standard errors on } a, b \\
\text { and } c\end{array}$ & $\begin{array}{c}\text { Regression } \\
\text { quality } \mathbf{R}^{2}\end{array}$ & $\begin{array}{c}\text { LOD } \\
\mathrm{mg} \mathrm{kg}^{-1}\end{array}$ & $\begin{array}{c}\text { LOQ } \\
\text { mg kg-1 }^{-1}\end{array}$ \\
\hline As & $1.25-12$ & $y=-0.0032 x^{2}+0.1599 x-0.0616$ & $0.0089 ; 0.0035 ; 0.0003$ & 0.9997 & 0.166 & 0.498 \\
\hline $\mathrm{Cd}$ & $5-15$ & $y=-0.0017 x^{2}+0.0566 x-0.1077$ & $0.0119 ; 0.0027 ; 0.0002$ & 0.9983 & 0.630 & 1.890 \\
\hline Co & $3-12$ & $y=-0.0075 x^{2}+0.1673 x-0.2153$ & $0.0034 ; 0.0011 ; 0.0001$ & 0.9999 & 0.062 & 0.186 \\
\hline $\mathrm{Cr}$ & $1-50$ & $y=0.0637 x+0.0204$ & $0.0301 ; 0.0012$ & 0.9956 & 1.736 & 5.041 \\
\hline $\mathrm{Cu}$ & $5-15$ & $\mathrm{y}=0.1381 \mathrm{x}-0.2347$ & $0.0030 ; 0.0003$ & 1.000 & 1.764 & 1.915 \\
\hline $\mathrm{Ni}$ & $1-15$ & $y=0.1036 x+0.2119$ & $0.0610 ; 0.0065$ & 0.9620 & 3.811 & 7.931 \\
\hline $\mathrm{Pb}$ & $5-25$ & $y=-0.0158 x^{2}+2.1287 x-3.2825$ & $0.2628 ; 0.0440 ; 0.0014$ & 0.9999 & 0.370 & 1.110 \\
\hline
\end{tabular}

High regression quality was obtained for all elements. Low detection limits, below

$1 \mathrm{mg} \mathrm{kg}^{-1}$ were obtained for all elements except $\mathrm{Cr}, \mathrm{Cu}$ and $\mathrm{Ni}$ for which LOD was 1.736 ,

1.764 and $3.811 \mathrm{mg} \mathrm{kg}^{-1}$ respectively (Table 3). If we consider the threshold of $\mathrm{Cr}$ and

$\mathrm{Ni}$ for multifunctional land use, where farmers can grow everything including the leaf succulent plants, are 50 and $40 \mathrm{mg} \mathrm{kg}^{-1}$ respectively [44], this means an error less than $3 \%$ and $4.4 \%$ for these two TEs, respectively. For agricultural crops and fruit trees, these values are reduced by 4 and 2.5 times, which means high reliability of results to orient land use policy and protect public health from TE transfer risks to food chain.

\subsubsection{Precision including repeatability and intermediate precision}

Precision is a measure of how close results are to one another, usually expressed by the standard deviation [45]. Repeatability is the test results obtained using the same method, 
on the same sample in the same laboratory, with the same equipment, by the same operator, in short intervals of time. Other terms are used to define repeatability, such as within-run, within-batch or intra-assay precision. Repeatability gives the smallest variation in results. Reproducibility is the test results obtained by different operators, different laboratories over a long period. It gives the largest variation in results. Between these two extremes, intermediate precision estimates result's variation in the same laboratory under routine conditions by different analysts and during an extended timescale. Other terms can be used to define intermediate precision such as between-run, between-batches, or inter-assay variation.

To determine repeatability and intermediate precision, two operators measured the metal concentrations in the soil CRM during each of the nine days. One-way ANOVA was applied on the obtained results. Repeatability was calculated as the within-group precision and expressed by the repeatability standard deviation Sr. It was calculated using the square root of the within-group mean square $\mathrm{MS}_{\mathrm{w}}$ :

$$
S_{r}=\sqrt{M S_{w}}
$$

Intermediate precision was calculated as the within-group and between-group precision and expressed by the intermediate precision standard deviation $\mathrm{Si}$. It was calculated by combining the within- and between-group variance.

$$
S_{i}=\sqrt{M S_{w}+\frac{M S_{b}-M S_{w}}{n}}
$$

$\mathrm{MS}_{\mathrm{b}}$ is the between-group mean square and $\mathrm{MS}_{\mathrm{w}}$ the within-group mean square. Both values were calculated from the one-way ANOVA table. Relative standard deviation RSD varied from $0.3 \%$ to $1.5 \%$ for the first operator and from $0.1 \%$ to $1.2 \%$ for the second operator. The higher RSD was obtained for Co whatever the operator was. 
Repeatability standard deviation varied from 0.43 to $2.46 \mathrm{mg} \mathrm{kg}^{-1}$. These values were relatively low and reflected good repeatability conditions (Table 4).

Table 4. Repeatability and intermediate precision results obtained after TE analysis of CRM soil using the microwave sulphuric digestion method ( $\mathrm{n}=9$ for both operators).

\begin{tabular}{|c|c|c|c|c|c|c|c|c|}
\hline \multirow[t]{2}{*}{ Parameters } & \multirow[t]{2}{*}{ units } & \multicolumn{7}{|c|}{ TE quantification } \\
\hline & & As & Cd & Co & $\mathrm{Cr}$ & $\mathrm{Cu}$ & $\mathbf{N i}$ & $\mathbf{P b}$ \\
\hline $\begin{array}{l}\text { Operator } 1 \\
\text { mean }\end{array}$ & $\mathrm{mg} \mathrm{kg}^{-1}$ & 151.5 & 165.5 & 186.3 & 98.5 & 233.8 & 123.7 & 126.4 \\
\hline SD & $\mathrm{mg} \mathrm{kg}^{-1}$ & 0.5 & 2.4 & 2.7 & 0.6 & 2.1 & 0.6 & 1.0 \\
\hline RSD & $\%$ & 0.3 & 1.4 & 1.5 & 0.6 & 0.9 & 0.5 & 0.8 \\
\hline $\begin{array}{l}\text { Operator } 2 \\
\text { mean }\end{array}$ & $\mathrm{mg} \mathrm{kg}^{-1}$ & 151.0 & 167.3 & 182.4 & 98.1 & 235.0 & 124.0 & 126.9 \\
\hline SD & $\mathrm{mg} \mathrm{kg}^{-1}$ & 0.9 & 0.7 & 2.2 & 0.4 & 0.2 & 0.1 & 0.5 \\
\hline RSD & $\%$ & 0.6 & 0.4 & 1.2 & 0.4 & 0.1 & 0.1 & 0.4 \\
\hline $\mathbf{S}_{\mathbf{r}}$ & $\mathrm{mg} \cdot \mathrm{kg}^{-1}$ & 0.70 & 1.76 & 2.46 & 0.49 & 1.52 & 0.43 & 0.76 \\
\hline $\mathbf{S}_{\mathrm{i}}$ & $\mathrm{mg} \mathrm{kg}^{-1}$ & 0.76 & 2.10 & 3.62 & 0.54 & 1.65 & 0.46 & 0.81 \\
\hline $\mathbf{R S}_{\mathbf{i}}$ & $\%$ & 0.5 & 1.3 & 2.0 & 0.5 & 0.7 & 0.4 & 0.6 \\
\hline
\end{tabular}

Intermediate precision varied between 0.46 and $3.62 \mathrm{mg} \mathrm{kg}^{-1}$, which represented 0.4 to $2.0 \%$ as the relative standard deviation. These relatively low values reflect an acceptable variation of the results obtained by the two operators who applied the same method under routine conditions. The acceptable value for repeatability depends on concentration and was set at $8 \%$ for samples at the $\mathrm{mg} \mathrm{kg}^{-1}$ level [46].

\subsubsection{Specificity}

The lack of specificity of a method can be due to the widening of the absorption signal, but most of the time, it is due to the presence of interfering elements, which could increase or hinder the signal of a specific element. Interfering compounds are various constituents of the matrix and/or the reagents used to prepare the sample. It is what is called matrix effects. The International Conference on Harmonisation [47] defined specificity as "the ability to assess unequivocally the analyte in the presence of components which may be expected to be present. Typically, this might include impurities, degradants, matrix, etc." 
It was evaluated by analysing the CRM soil alone and after addition of known quantities of each element. Two levels of concentration for each element were added to the CRM soil: 50 and $100 \mathrm{mg} \mathrm{kg}^{-1}$. Samples were labelled CRM, CRM1 and CRM2. Samples were digested in triplicate and each sample was measured 3 times. The specificity was calculated using the recovery ratio expressed in percentage:

$R(\%)=\frac{\text { experimental quantity after standard addition }- \text { experimental quantity before standard addition }}{\text { known added quantity }} \times 100$

The mean recovery of samples CRM, CRM1 and CRM2 and their respective standard deviations, for all the being studied elements are gathered in Table 5.

Table 5. Specificity results expressed as mean recovery percentage and standard deviation. Three samples were analysed: CRM soil alone and CRM after the addition of two concentration levels for each element $(n=9)$.

\begin{tabular}{|c|c|c|c|}
\hline \multirow[t]{2}{*}{$\begin{array}{c}\text { Trace } \\
\text { elements }\end{array}$} & \multicolumn{3}{|c|}{$\begin{array}{l}\text { Mean recovery percentage and standard deviation } \\
\%\end{array}$} \\
\hline & Soil CRM & $\begin{array}{c}\text { Soil CRM 1 } \\
+50 \mathrm{mg} \mathrm{kg}^{-1} \text { of each TE }\end{array}$ & $\begin{array}{c}\text { Soil CRM } 2 \\
+100 \mathrm{mg} \mathrm{kg}^{-1} \text { of each TE } \\
\end{array}$ \\
\hline As & $93.7 \pm 0.9$ & $96.1 \pm 9.6$ & $104.0 \pm 4.9$ \\
\hline Cd & $87.3 \pm 4.7$ & $94.7 \pm 9.2$ & $92.0 \pm 6.3$ \\
\hline Co & $112.6 \pm 0.1$ & $116.9 \pm 0.3$ & $117.8 \pm 0.8$ \\
\hline $\mathrm{Cr}$ & $112.3 \pm 3.5$ & $111.5 \pm 7.2$ & $109.9 \pm 5.7$ \\
\hline $\mathrm{Cu}$ & $89.2 \pm 3.9$ & $90.6 \pm 4.0$ & $99.1 \pm 4.9$ \\
\hline $\mathbf{N i}$ & $98.4 \pm 0.9$ & $98.1 \pm 2.1$ & $97.7 \pm 1.7$ \\
\hline $\mathbf{P b}$ & $112.6 \pm 0.1$ & $116.9 \pm 0.2$ & $117.8 \pm 0.8$ \\
\hline
\end{tabular}

The specificity results show that the recovery percentages of all elements are within [80 - 120\%] interval. Specificity values for TEs in soil have not been found in the literature. However, EU commission regulation No 2001/22/EC [48] mentions that recovery between $80-120 \%$ is acceptable for TEs such as lead, cadmium and mercury 
in foodstuffs. These results allow the application of the developed method in routine analysis without causing interference for $\mathrm{As}, \mathrm{Cd}, \mathrm{Co}, \mathrm{Cr}, \mathrm{Cu}, \mathrm{Ni}$ and $\mathrm{Pb}$.

\subsubsection{Comparison between the validated method $(M S D+A A S)$ and the RTD}

method (HF-based digestion + ICP/ICPMS) of TE analysis. Accuracy or trueness.

Accuracy is defined as "the closeness of agreement between the value which is accepted either as a conventional true value or an accepted reference value and the value found" [47]. Accuracy is sometimes defined as trueness. Accuracy can be determined by analysing a CRM and comparing the experimental value to the assigned value. It is actually what we did in paragraph 3.1 where we obtained recovery percentages between 87 and $112 \%$. Another way to assess accuracy is to work on real samples, to analyse them by the method being validated and to compare results with that obtained from a reference method. In this study, TEs in soil samples from the Bekaa governorate were determined by an MSD method using a mixture of $\mathrm{H}_{2} \mathrm{SO}_{4}$ and $\mathrm{H}_{2} \mathrm{O}_{2}$ followed by AAS measurements. Microwave digestion and element analysis were done in triplicate. Results from this method were compared to an external ISO reference which is the RTD method where the same samples were digested by $\mathrm{HF}$ and $\mathrm{HClO}_{4}$ and analysed by ICP-AES or ICP-MS. The RTD method allows for total digestion of soil samples.

Results were compared in terms of recovery percentage calculated using equation 1 . They are presented in Table 6. 
1 Table 6. Comparison between the MSD method $\left(\mathrm{H}_{2} \mathrm{SO}_{4}+\mathrm{H}_{2} \mathrm{O}_{2}\right.$ digestion) being validated and the RTD method ( $\mathrm{HF}+\mathrm{HClO}_{4}$ digestion) for TEs in soil samples from the Bekaa governorate sites. Sites

As

Co Trace elements

\begin{tabular}{|c|c|c|c|c|c|c|c|c|c|c|c|c|c|c|c|c|c|c|}
\hline \multirow[b]{2}{*}{ B1 } & \multicolumn{2}{|c|}{$\begin{array}{c}\mathbf{R T D} \pm \mathrm{SD} \underset{\mathrm{mg} \mathrm{kg}}{\mathbf{M}} \\
\mathbf{M S D} \pm \mathrm{SD}\end{array}$} & $\begin{array}{l}\text { Rec. } \\
\%\end{array}$ & \multicolumn{2}{|c|}{$\begin{array}{c}\text { RTD } \pm \text { SD MSD } \pm \text { SD } \\
\mathrm{mg} \mathrm{kg}^{-1}\end{array}$} & \multirow{2}{*}{$\begin{array}{c}\text { Rec. } \\
\% \\
55\end{array}$} & \multicolumn{2}{|c|}{$\begin{array}{c}\mathbf{R T D} \pm \mathrm{SD} \underset{\mathrm{mg} \mathrm{kg}}{\operatorname{MSD}} \pm \mathrm{SD} \\
\end{array}$} & \multirow{2}{*}{$\begin{array}{c}\text { Rec. } \\
\% \\
63\end{array}$} & \multicolumn{2}{|c|}{$\begin{array}{c}\text { RTD } \pm \text { SD MSD } \pm \text { SD } \\
\mathrm{mg} \mathrm{kg}^{-1}\end{array}$} & \multirow{2}{*}{$\begin{array}{c}\text { Rec. } \\
\% \\
82\end{array}$} & \multicolumn{2}{|c|}{$\begin{array}{c}\mathbf{R T D} \pm \mathrm{SD} \quad \mathbf{M S D} \pm \mathrm{SD} \\
\mathrm{mg} \mathrm{kg}^{-1}\end{array}$} & \multirow{2}{*}{$\begin{array}{c}\text { Rec. } \\
\% \\
70\end{array}$} & \multicolumn{2}{|c|}{$\begin{array}{c}\mathbf{R T D} \pm \mathrm{SD} \quad \mathbf{M S D} \pm \mathrm{SD} \\
\mathrm{mg} \mathrm{kg}^{-1}\end{array}$} & \multirow{2}{*}{$\begin{array}{c}\text { Rec. } \\
\% \\
83\end{array}$} \\
\hline & $6.8 \pm 0.4$ & $3.3 \pm 0.0$ & 48 & $18.3 \pm 2.0$ & $10.0 \pm 0.0$ & & $94.1 \pm 12.8$ & $59.6 \pm 0.1$ & & $22.0 \pm 1.7$ & $18.1 \pm 0.1$ & & $56.1 \pm 3.0$ & $39.4 \pm 0.2$ & & $13.8 \pm 0.8$ & $11.5 \pm 0.0$ & \\
\hline B2 & $4.5 \pm 0.2$ & $3.1 \pm 0.0$ & 69 & $13.3 \pm 1.7$ & $9.7 \pm 0.0$ & 73 & \pm 11.6 & $60.7 \pm 0.1$ & 72 & $8 \pm 1.6$ & $16.3 \pm 0.1$ & 83 & $47.3 \pm 2.7$ & $25.6 \pm 0.2$ & 54 & $16.8 \pm 1.0$ & $2.3 \pm 0.0$ & 73 \\
\hline B3 & $4.4 \pm 0.2$ & $4.2 \pm 0.0$ & 95 & & & 85 & & & 67 & & & 78 & & & 63 & 1.5 & & 81 \\
\hline B4a & $7.3 \pm 0.4$ & 4.2 & 57 & .6 & 10. & 94 & 8.5 & .1 & 77 & & 1.0 & 91 & & & 102 & 0.6 & & 66 \\
\hline B4b & $7.5 \pm 0.4$ & & 55 & \pm 1.6 & ).1 & 89 & \pm 8.6 & 43.9 & 77 & 1.4 & 0.2 & 100 & 2.4 & 0.6 & 99 & $=0.6$ & 0.0 & 73 \\
\hline B5 & $11.3 \pm 0.6$ & \pm 0.0 & 87 & \pm 2.3 & $7.3 \pm 0.1$ & 69 & $29.0 \pm 16.7$ & 68.2 & 53 & 1.8 & 0.1 & 56 & $=3.9$ & 0.1 & 59 & $17.5 \pm 1.1$ & $15.5 \pm 0.1$ & 89 \\
\hline B6 & $6.4 \pm 0.4$ & $4.2 \pm 0.0$ & 66 & \pm 1.9 & $13.4 \pm 0.1$ & 90 & $71.7 \pm 10.8$ & $50.4 \pm 0.0$ & 70 & $0 \pm 1.8$ & $16.5 \pm 0.0$ & 72 & $0 \pm 2.7$ & $50.2 \pm 0.1$ & 96 & $5.0 \pm 0.9$ & $5.7 \pm 0.0$ & 38 \\
\hline B7 & $7.7 \pm 0.4$ & $4.3 \pm 0.0$ & 55 & \pm 2.5 & $17.0 \pm 0.0$ & 89 & $94.3 \pm 10.7$ & $90.4 \pm 0.0$ & 96 & \pm 1.9 & $16.8 \pm 0.0$ & 70 & $.5 \pm 3.0$ & $50.4 \pm 0.0$ & 86 & $18.6 \pm 1.1$ & $5.8 \pm 0.0$ & 31 \\
\hline B8 & $9.7 \pm 0.5$ & $8.2 \pm 0.0$ & 85 & $23.0 \pm 2.2$ & $16.7 \pm 0.1$ & 72 & $114.0 \pm 15.0$ & $71.2 \pm 0.1$ & 62 & $25.9 \pm 1.8$ & $15.6 \pm 0.0$ & 60 & $64.2 \pm 3.3$ & $39.2 \pm 0.1$ & 61 & $19.5 \pm 1.2$ & $17.3 \pm 0.1$ & 89 \\
\hline
\end{tabular}

RTD = Reference Total Digestion method mean value; MSD = Microwave Sulphuric Digestion method mean value; Rec. = mean Recovery; SD = Standard deviation 
All recovery values were below $100 \%$, which was predictable because the MSD with a mixture of $\mathrm{H}_{2} \mathrm{SO}_{4}$ and $\mathrm{H}_{2} \mathrm{O}_{2}$ does not induce a total mineralization of silicates compared with the RTD method using a mixture of $\mathrm{HF}$ and $\mathrm{HClO}_{4}$. High recovery percentages were obtained for $\mathrm{Co}, \mathrm{Cr}$ and $\mathrm{Cu}$. Two-thirds of the calculated recoveries were higher than $70 \%$, which is an acceptable value for trace analysis as defined by (AOAC 2002) [46]. The other third was between 50 and 70\% except for 3 values (As for $\mathrm{B} 1$ and $\mathrm{Pb}$ for $\mathrm{B} 6$ and $\mathrm{B} 7$ ). $\mathrm{As}, \mathrm{Co}, \mathrm{Cr}$ and $\mathrm{Pb}$ concentrations measured using the validated MSD method were correlated with values obtained using the RTD method. The relation was greatly improved for $\mathrm{Pb}\left(\mathrm{R}^{2}=0.9624^{*}\right.$ with a slope $=$ 1.0486) when B6 and B7 were removed. For Cr, the relationship was greatly improved when B7 was not considered $\left(\mathrm{R}^{2}=0.9074 *\right)$ and indicated a reduction of the recovery percentage with increased total concentrations. The most contaminated soil was B5, with the highest concentrations for $\mathrm{As}, \mathrm{Co}, \mathrm{Cr}, \mathrm{Cu}$ and $\mathrm{Ni}$. This plot is occasionally irrigated by pumping water from an irrigation canal from the Berdawni River, the catchment of which drains the town of Zahleh. Nevertheless, all soils remained in the lower range of concentrations found in soils worldwide for all elements [14]. Cobalt, $\mathrm{Cr}, \mathrm{Cu}$ and $\mathrm{Ni}$ concentrations were correlated indicating a probable common geogenic origin. Arsenic was only correlated to $\mathrm{Co}$ and $\mathrm{Ni}$, which may be related to a more scattered occurrence due to anthropogenic inputs [49]. The lead concentration was not correlated to that of any of the other elements, probably because two soils (B6 and B7) had a very low recovery rate. These results confirm the reported low content in the soils of the Central Bekaa area and depicted from the spatial distribution of total $\mathrm{Pb}$ in the soil surface [50]. The pattern of $\mathrm{Pb}$ concentration shows, above a weak geogenic background (4 - $14 \mathrm{mg} \mathrm{kg}^{-1}$ ), an anthropic contamination along heavy trafficked roads by atmospheric deposition [51] and surface accumulation gradient of $\mathrm{Pb}$ from foot-slope, located downslope of Zahleh town, towards the Litani River (14 - $34 \mathrm{mg} \mathrm{kg}^{-1}$ ). This lead is carried by water runoff from Zahleh agglomeration (see Figure S1, Supplementary Materials SM4). 
Arsenic values obtained by the RTD method varied between $4.35 \mathrm{mg} \mathrm{kg}^{-1}$ for B3 and $11.3 \mathrm{mg} \mathrm{kg}^{-1}$ for B5. They were slightly above the commonly reported mean background As concentrations in surface soils (worldwide data) [14], but still within the range for common, possible background values and multifunctional land use [44].

Cadmium values were not shown in this study because they were below quantification limit (1.89 $\left.\mathrm{mg} \mathrm{kg}^{-1}\right)$ when using the MSD validated method. Cd could not be determined by this method. However, all values determined by the RTD method varied between $0.23 \mathrm{mg} \mathrm{kg}^{-1}$ for B4b and $0.48 \mathrm{mg} \mathrm{kg}^{-1}$ for B8 and were defined within the global average soil Cd concentration (0.06 - $\left.1.1 \mathrm{mg} \mathrm{kg}^{-1}\right)$ [14]. Our values are in agreement with those found by Kanbar et al. $\left(0.28-2.8 \mathrm{mg} \mathrm{kg}^{-1}\right)$ in different Lebanese soils [52] and those found by Darwish in Bekaa soils $\left(0.28-0.48 \mathrm{mg} \mathrm{kg}^{-1}\right)[7]$.

Cobalt values obtained by the RTD method varied between $11.4 \mathrm{mg} \mathrm{kg}^{-1}$ for B3 and $25.2 \mathrm{mg} \mathrm{kg}^{-1}$ for B5. These values are close to the range of world values in surface soils (4.5 - $12 \mathrm{mg} \mathrm{kg}^{-1}$ ) [14]. They are comparable to those obtained for arid and semiarid regions (16.5 - $\left.26.8 \mathrm{mg} \mathrm{kg}^{-1}\right)$ [53]. They are also in agreement with those found by Darwish in Bekaa soils (28.1- $\left.28.5 \mathrm{mg} \mathrm{kg}^{-1}\right)$ [7].

Chromium values obtained by the RTD method varied between $55.8 \mathrm{mg} \mathrm{kg}^{-1}$ for B4a and $129.0 \mathrm{mg} \mathrm{kg}^{-1}$ for B5. These values are higher than the world median content of $\mathrm{Cr}$ in soils: $54 \mathrm{mg} \mathrm{kg}^{-1}$. They are within the sandy and light loamy soils range, which contains $\mathrm{Cr}$ between 2 and $350 \mathrm{mg} \mathrm{kg}^{-1}$ [14]. They are close to those found by Darwish in Bekaa soil samples (43.3 and $71.3 \mathrm{mg} \mathrm{kg}^{-1}$ ) [7] and do not exceed the limits for safe agricultural land use.

Copper values obtained by the RTD method varied between $14.5 \mathrm{mg} \mathrm{kg}^{-1}$ for B4b and $27.9 \mathrm{mg} \mathrm{kg}^{-1}$ for B5. These results are within the range for $\mathrm{Cu}$ concentration in soils $\left(8 \mathrm{mg} \mathrm{kg}^{-}\right.$ ${ }^{1}$ in acid sandy soils to $80 \mathrm{mg} \mathrm{kg}^{-1}$ in heavy loamy soils) [14]. They are in general lower than 
those obtained in other Lebanese soils (25.3 - $\left.54.2 \mathrm{mg} \mathrm{kg}^{-1}\right)$ [52], among others Taalabaya (Zahleh district) soils (35.7 $\mathrm{mg} \mathrm{kg}^{-1}$ ) [7], but conform to the values obtained in Saadnaeal (Zahleh district) soils $\left(17.0 \mathrm{mg} \mathrm{kg}^{-1}\right)$.

Nickel values obtained by the RTD method varied between $39.4 \mathrm{mg} \mathrm{kg}^{-1}$ for B4a and $78.9 \mathrm{mg} \mathrm{kg}^{-1}$ for B5. These values are within the range of $\mathrm{Ni}$ concentration in soils worldwide $\left(0.2-450 \mathrm{mg} \mathrm{kg}^{-1}\right)$ [14]. They are in agreement with values obtained in Taalabaya soils (60.7 $\left.\mathrm{mg} \mathrm{kg}^{-1}\right)$ but higher than values obtained in Saadnaeal soils sampled at the same depth (33.7 $\left.\mathrm{mg} \mathrm{kg}^{-1}\right)$ [7].

Lead values obtained by the RTD method varied between $8.84 \mathrm{mg} \mathrm{kg}^{-1}$ for B4b and $24.48 \mathrm{mg} \mathrm{kg}^{-1}$ for $\mathrm{B} 3$. They are lower than the overall mean value of $\mathrm{Pb}$ in different soils worldwide $\left(25 \mathrm{mg} \mathrm{kg}^{-1}\right)$ [14]. They are in agreement with those obtained in other Lebanese soils (11.3 - $\left.22.9 \mathrm{mg} \mathrm{kg}^{-1}\right)$ [52] and those obtained in Taalabaya soils $\left(16.7 \mathrm{mg} \mathrm{kg}^{-1}\right)$ and Saadnaeal soils $\left(10.0 \mathrm{mg} \mathrm{kg}^{-1}\right)$ [7].

In summary, the results obtained in this study are representative of soils with limited trace elements contamination. The concentrations measured are within the same range than the values obtained by Darwish for surface soils and soil profiles of the Bekaa plain. He points to both a natural TE source with variation explained by the alluvial-colluvial origin of the parent material but also to a limited anthropogenic pollution due to a combination of inputs from cultivation and atmospheric deposition which is modulated by soil organic content.

The correlations between TEs values were higher following the RTD method than the validated one, suggesting that the RTD method can better trace the common origin of the elements, which was mostly of geogenic origin, as also indicated by the observed level of concentrations, which were close to the background level detected in North Lebanon [8]. 
Aqua regia, which is a reference method for pseudo-total metal concentrations in soils, gives extraction efficiency between 53 and $100 \%$, depending on the element, as compared to total concentrations (calculated for the certified material METRANAL-33 in Shahbazi and Beheshti) [54]. Although it is widely used, resorption occurs (up to $470 \%$ for $\mathrm{Cu}$ ) leading to underestimation of element concentrations [55] and other mild extraction procedures may provide accurate results when trace element reactive fraction, not bound to silicates, is to be recovered [55]. Our results fall within the same range of efficiency as aqua regia and the validated method including the microwave digestion with $\mathrm{H}_{2} \mathrm{SO}_{4}+\mathrm{H}_{2} \mathrm{O}_{2}$ may offer a more feasible and workable alternative.

\section{Conclusion}

The microwave digestion with $\mathrm{H}_{2} \mathrm{SO}_{4}+\mathrm{H}_{2} \mathrm{O}_{2}$ combined with flame-AAS measurement was validated with CRM and after comparison with HF-based digestion. It allows for routine but accurate characterization of calcareous and Ca-saturated soils with limited contamination in As, $\mathrm{Cd}, \mathrm{Cu}, \mathrm{Co}, \mathrm{Cr}$ and $\mathrm{Pb}$. The tested soils, used for wheat production, are irrigated with water of poor quality and need to be monitored for their trace element concentrations regularly to prevent transfer to the food chain.

Recent microwave digestion methods were implemented according to green chemistry, they have proved their efficiency for the determination of trace elements in soil samples $[11,12,19,22]$. In these studies, several reagents were used to dissolve soil or sediment samples such as: $\mathrm{HNO}_{3}, \mathrm{HClO}_{4}, \mathrm{HF}, \mathrm{HCl}, \mathrm{NH}_{4} \mathrm{HF}_{2}$ and $\mathrm{H}_{2} \mathrm{O}_{2}$ before trace element analysis using ICPOES, ICP-MS or MIP-OES. These recent methods uses problematic reagents difficult to handle safely and/or very expensive analytical devices.

The validated method offers an alternative to HF-based methods, as well as aqua regia. It is green, safe and cheap method for trace element analysis in soil samples. Other soil types 
100 will have to be tested in order to further extend its use to a larger range of soils to cover the soil 101 diversity in the Mediterranean area. 
103 [1] M.B. Rivera, J.C. Fernández-Caliani and M.I. Giráldez, Geoderma. 259-260, 164 (2015).

[2] E. Shang, E. Xu, H. Zhang and C. Huang, Sci. Rep. 9, 19463 (2019).

[3] V. Antoniadis, E.E. Golia, Y.-T. Liu, S.-L. Wang, S.M. Shaheen and J. Rinklebe, Environ. Int. 124, 79 (2019).

[4] L.N. Kassir, T. Darwish, A. Shaban, G. Olivier and N. Ouaini, Geoderma. 189-190, 357 (2012).

[5] S.I. Korfali and H. Karaki, Environ. Process. 5, 101 (2018).

[6] T. Darwish, I. Jomaa, M. Awad and R. Boumetri, Leb. Sci. J. 9, 3 (2008).

[7] T. Darwish, presented at Global Symposium on Soil Pollution, FAO, Rome, Italy, 2018: pp. 8591.

[8] B. Nsouli, T. Darwish, J.-P. Thomas, K. Zahraman and M. Roumié, Nucl. Instrum. Methods Phys. Res., Sect. B. 219-220, 181 (2004).

[9] C. Voica, A. Dehelean, A. Iordache and I. Geana, Romanian Reports in Physics. 64, 221 (2012).

[10] R.A.A. Munoz, E.S. Almeida and L. Angnes, in Reference Module in Chemistry, Molecular Sciences and Chemical Engineering, edited by Elsevier (2013).

[11] I. Funes Pinter, M.V. Salomon, R. Gil, L. Mastrantonio, R. Bottini and P. Piccoli, Sci. Total Environ. 615, 1485 (2018).

[12] T. Lin, X. Chen, B. Li, P. Chen, M. Guo, X. Zhou, S. Zhong and X. Cheng, Microchem. J. 146, 49 (2019).

[13] C.T.T. Nguyen, R.J. Wasson, E.S. Estrada, S.I. Cantarero, C. Teo and A.D. Ziegler, J. Environ. Manage. 232, 999 (2019).

[14] A. Kabata-Pendias and A.B. Mukherjee, Trace Elements from Soil to Human (Springer-Verlag, Berlin Heidelberg, 2007).

[15] M. Hoenig, Talanta. 54, 1021 (2001).

[16] S. Melaku, R. Dams and L. Moens, Anal. Chim. Acta. 543, 117 (2005).

[17] A. Santoro, A. Held, T.P.J. Linsinger, A. Perez and M. Ricci, TrAC, Trends Anal. Chem. 89, 34 (2017).

[18] W. Zhang and Z. Hu, Spectrochim. Acta, Part B. 160, 105690 (2019).

[19] T.T. Magaldi, M.S. Navarro and J. Enzweiler, Geostand. Geoanal. Res. 43, 189 (2019).

[20] ISO 22036:2008. Soil quality. Determination of trace elements in extracts of soil by inductively coupled plasma - atomic emission spectrometry (ICP - AES), ISO. (2008).

[21] ISO 17294-2:2016. Water quality. Application of inductively coupled plasma mass spectrometry (ICP-MS). Part 2: Determination of selected elements including uranium isotopes, ISO. (2016).

[22] F. Cora Jofre, D.N. Larregui and M. Savio, Microchem. J. 159, 105448 (2020).

[23] C.A. Bizzi, M.F. Pedrotti, J.S. Silva, J.S. Barin, J.A. Nóbrega and E.M.M. Flores, J. Anal. At. Spectrom. 32, 1448 (2017).

[24] Food and Agriculture Organization, Résultats globaux du module de base du recensement de l'agriculture 2010.

[25] IUSS Working Group WRB, World reference base for soil resources 2014 International soil classification system for naming soils and creating legends for soil maps, World Soil Resources Reports No. 106. FAO, Rome, $2015 . \quad<$ https://ec.europa.eu/jrc/en/publication/worldreference-base-soil-resources-2014-international-soil-classification-system-naming-soils-and>.

[26] W. Horwitz, Pure Appl. Chem. 62, 1193 (1990).

[27] NF X31-102. Soils quality. Determination of resudual moisture content of soils analytical test samples, (1981).

[28] ISO 11464:2006. Soil quality. Pretreatment of samples for physico-chemical analysis, (2006).

[29] ISO 14869-1:2001. Soil quality. Dissolution for the determination of total element content. Part 1: Dissolution with hydrofluoric and perchloric acids, (2001).

[30] RCore Team, R: A language and environment for statistical computing (Vienna, Austria, 2020).

[31] RStudio Team, RStudio: Integrated Development for R. RStudio (PBC, Boston, MA, 2020). 
[32] J. Fox and S. Weisberg, An R companion to applied regression (Sage publications, California, US, 2018).

[33] A. Zeileis and T. Hothorn, R News. 2, 7 (2002).

[34] H. Wickham, A Grammar of Data Manipulation. R package version 0.8. 5. 700, R-Project. Org/Package= Dplyr. (2020).

[35] S. Révillon and D. Hureau-Mazaudier, Geostand. Geoanal. Res. 33, 397 (2009).

[36] H. Hernández-Mendoza, M. Mejuto, A.I. Cardona, A. García-Álvarez, R. Millán and A. Yllera, Am. J. Anal. Chem. 4, 9 (2013).

[37] D.B. Hibbert and J.J. Gooding, Data Analysis for Chemistry: An Introductory Guide for Students and Laboratory Scientists (Oxford University Press, Oxford, New York, 2005).

[38] W.P. Gardiner, Statistical Analysis Methods for Chemists (Royal Society of chemistry, 1997).

[39] B.J. Millard, Quantitative mass spectrometry (Heyden, 1978).

[40] I. Lavagnini and F. Magno, Mass Spectrom. Rev. 26, 1 (2007).

[41] A.M. Committee, Analyst. 119, 2363 (1994).

[42] Á. Lavín, J.D. Vicente, M. Holgado, M.F. Laguna, R. Casquel, B. Santamaría, M.V. Maigler, A.L. Hernández and Y. Ramírez, Sensors. 18, 2038 (2018).

[43] J.S. Garden, D.G. Mitchell and W.N. Mills, Anal. Chem. 52, 2310 (1980).

[44] Federal Office for the Environment, Sols pollués. Évaluation de la menace et mesures de protection. Cf Eikmann and Klocke, 1993 (2005).

[45] V. Barwick, P.P.M. Bravo, S.L. Ellison, J. Engman, E.L. Gjengedal, U.O. Lund, B. Magnusson, H.-T. Müller, M. Patriarca and B. Pohl, The fitness for purpose of analytical methods, edited by B. Magnusson and U. Örnemark (Eurachem, 2014).

[46] W. Horwitz, AOAC guidelines for single laboratory validation of chemical methods for dietary supplements and botanicals, Gaithersburg (MD, USA: AOAC International. 2002) pp. 12-9.

[47] International Conference on Harmonisation, Q 2 (R1) Validation of Analytical Procedures: Text and Methodology, 1996.

[48] European Commission, Commission Directive 2001/22/EC of 8 March 2001 laying down the sampling methods and the methods of analysis for the official control of the levels of lead, cadmium, mercury and 3-MCPD in foodstuffs, Official Journal. 50, 14 (2001).

[49] T. Darwish, M. Hamze and B. Nsouli, Lebanese Science Journal (in Press). (2021).

[50] T. Darwish, H.W. Mueller, M. Hobler, and I. Jomaa, Approach to assess soil contamination II: Evaluation of heavy metal contamination of main arable Lebanese soils, in: Marrakech, Morocco: 131-133, 2004.

[51] V. Gupta, in Environmental Concerns and Sustainable Development: Volume 1: Air, Water and Energy Resources, edited by V. Shukla and N. Kumar (Springer, Singapore, 2020) pp. 113-127.

[52] H.J. Kanbar, N. Hanna, A.G. El Samrani, V. Kazpard, A. Kobaissi, N. Harb and N. Amacha, Environ. Monit. Assess. 186, 8793 (2014).

[53] M. Jalali and M. Majeri, Geochem. 76, 95 (2016).

[54] K. Shahbazi and M. Beheshti, Comparison of three methods for measuring heavy metals in calcareous soils of Iran, SN Appl. Sci. 1, 1541 (2019).

[55] L.G. Guedes, V.F. Melo and A.H. Batista, The classic aqua regia and EPA $3051 \mathrm{~A}$ methods can mislead environmental assessments and certifications: Potentially harmful elements resorption in short-range order materials, Chemosphere. 251, 126356 (2020). 